\title{
Early Modern Merchant’s Marks in Medieval English Books
}

Between 1532 and 1538, Hans Holbein the Younger painted a series of portraits of Hanseatic merchants residing at the London Steelyard, the headquarters of the League in the city. ${ }^{1}$ The most elaborate of these works is the image of Georg Gisze (1532), a merchant from Danzig who was stationed at the Steelyard from 1522 until the mid-1530s (figure 1 ). ${ }^{2}$ His portrait shows him at work in his office, about to open a letter addressed to him 'to lunden / in engelant' ('at London in England'). ${ }^{3}$ Behind him are shelves piled with books, scales, and other objects relating to his profession. On the wall are two sets of railings, behind which are tucked opened letters. Two of these letters bear Gisze’s merchant's mark. The mark is formed from a cross with a vertical line through the left bar and a line extending diagonally down and right from the centre. In Gisze’s painting, the mark identifies him on his correspondence, and is suggestive of the international mercantile world of which he was a part.

Twelve years later, in 1544, twenty-six year old mercer Thomas Gresham was preparing for his wedding to Anne Ferneley, and as part of the marriage celebrations commissioned a portrait of himself (figure 2). ${ }^{4}$ The portrait records Gresham early in his career, and was probably painted in Flanders where he was stationed at the time. ${ }^{5}$ Gresham stands against a blank wall in three sections. The middle is at an angle and in shadow, emphasising his darkly-clad figure. To the left of his head is inscribed the year, his name in majuscule letters, and his age. Below this is Gresham's merchant's mark, an inverted triangle with rounded upper corners, split into three sections containing his initials and the letter ' $O$ ' in the same majuscules. From the triangle rises a line, at the top of which is an X-shaped cross sitting between the two digits of '26'. To the right of Gresham are the couple's initials, 'AG' and 'TG', with the motto 'LOVE • SERVE • / AND • OBEI •’ in between. The portrait is stark and monumental, and the mark prominently displayed. It speaks not only to 
the family and friends of the newlyweds, but to Gresham's colleagues and contacts in the Mercer’s Company and beyond.

Merchant's marks were symbols of identification associated, as their name implies, with merchants and traders. They were used from at least the thirteenth century up to the seventeenth century. ${ }^{6}$ They developed as marks of ownership on goods and consignments, and could be associated with an individual or a group. Marks were not employed exclusively by merchants: people from a range of professions used 'personal marks' to identify themselves in a range of contexts, but the term 'merchant's mark' commonly refers to all such symbols and is used in this sense here. ${ }^{7}$

Marks were often graphically simple, constructed around a vertical stem with detail at the top and bottom, reflecting the need for them to be easy and quick to write. Later examples, including some discussed here, could be more elaborate. Initials and other complex embellishments came to be incorporated in their design, possibly suggesting that such examples were no longer used in ways that required simplicity and speed. A shift in use from an identifier in trade bureaucracy and logistics to something more like a personal device might explain why, by the late middle ages, marks were sometimes set in heraldic shields as though a coat of arms. ${ }^{8}$ Merchants were occasionally reproved for this practice, suggesting conflict over the social signification of their marks; as a symbol of professional, and commoner, status, their elevation to a symbol of nobility seems to have caused tension. ${ }^{9}$

Despite the potentially rich resonances of the marks in the images of Gisze and Gresham, they have rarely been discussed by art historians. ${ }^{10}$ This situation is mirrored in medieval and early modern bibliographical studies, with which this essay is concerned. Histories of the late medieval and Tudor book and studies of book ownership in these periods have tended to privilege external archival evidence, such as wills, booklists, and inventories, over evidence found in situ. ${ }^{11}$ More common in printed books than in manuscripts, the 
appearance of marks in the devices of early printers in England has occasionally been commented on, but remarks on their appearance in manuscripts are few. ${ }^{12}$

The archival focus of research into book ownership may lie behind the neglect of merchant's marks since they were first studied in the nineteenth century by local historians and antiquaries. ${ }^{13}$ Edward Mars Elmhirst produced a catalogue of marks in 1959 drawing on this previous work, and in 1962 F. A. Girling published a study in which he surveyed English examples in stone, wood, and brass. ${ }^{14}$ Both authors noted marks in early printed books, but neither made detailed mention of manuscripts. ${ }^{15}$ This lack of emphasis on bibliographical examples has created the impression that merchant's marks were used only by craftspeople, and only in the middle ages. Matthew Champion includes a chapter on marks in a recent book on medieval graffiti; again, his examples are largely drawn from medieval stonework. ${ }^{16}$ However, the majority of merchant's marks found in books belong to Tudor owners and date from the sixteenth century. Period boundaries lose further purchase on this subject because such marks often appear in books produced in the previous century. This blurring may reflect contemporary experience: perhaps sixteenth-century mercantile owners of medieval books did not yet perceive them as the antiquities later collectors sought to preserve and protect.

Early scholarship on merchant's marks tended to isolate them from their material contexts and to focus on cataloguing and on their origins and development. In recent decades, though, bibliographers of both medieval and early modern books have moved away from this kind of abstraction. Attention has increasingly been paid to the physical traces left by past owners and users as part of a fuller material history. Many studies, particularly by scholars of early modern England, have examined such evidence for what it says about contemporary reading practices, but there is much else to be learned from the close examination of markings in books. ${ }^{17}$ As nonverbal signifiers, merchant’s marks alert us to aspects of book use which are not, or are only indirectly, related to the texts they contain. Indeed, some of the 
owners discussed here appear not to have been interested in reading the manuscripts they bought. So, in line with a smaller body of work across the medieval and early modern periods, this essay will examine merchant's marks as evidence for a broader range of practices. ${ }^{18}$ The examples below will suggest how merchant's marks positioned professional identity relative to other expressions of status, and how, in combination with the acquisition and transfer of sometimes lavish medieval books, they reflect the pursuit of social advancement by their sixteenth-century owners.

Merchant's marks were mostly inscribed in medieval manuscripts as symbols of ownership rather than sale. This distinction is significant because some early modern books, including the first printed texts which circulated in Britain in the early sixteenth century, were marked in the opposite way. This kind of book often incorporated a merchant's mark in its printer's device: examples include Ursyn Mylner’s 1516 print of Whitinton’s Grammar at York, Robert Copland's 1534 print for John Byddell of an English translation of Erasmus' Funus at London, and Wynkyn de Worde's print for the Oxford stationer Henry Jacobi of the Formalitates of Antonius Sirectus. ${ }^{19}$ North of the border, the device of Andro Myllar, who in partnership with Walter Chepman established the first press in Scotland in the first decade of the sixteenth century, contained Myllar’s mark. ${ }^{20}$ Most famously, William Caxton used a mark formed from two intersecting lines as his printer's device. ${ }^{21}$ These examples testify to the conditions in which early printed books were produced, resulting from the business efforts of men who already had mercantile associations. They also suggest that it may have been conventional to incorporate marks in printer's devices, part of the packaging of printed material for purchase and consumption. 
In contrast, marks added to medieval manuscripts tend not to signify the involvement of merchants in the production and marketing of books, but were instead later additions. Even a manuscript incorporating a merchant's mark in almost its original design was inscribed for its owner, rather than its retailer. ${ }^{22}$ This book, the Browne Hours, was produced in Bruges for the English market in the second half of the fifteenth century and bought by John Browne, who had a miniature painted on $\mathrm{f}$. $7 \mathrm{v}$ surrounded by a border into which his mark was inscribed. $^{23}$

Many manuscripts reveal much less about their early history, and merchant’s marks are sometimes unaccompanied by names or explicit indications of ownership. Visual clues, like the use of layout and pattern, offer evidence for the use of marks to signify ownership. Visual dynamics of this sort are at work in one of the manuscripts written by John Shirley, the fifteenth-century scribe credited with the preservation and attribution of a number of Chaucer’s short poems. ${ }^{24}$ This book, a literary anthology containing 'Certen peeces of Lydgates, Chaucers and Gowres woorkes' (f. ii r) as an early modern annotator of the manuscript put it, is thought to be Shirley’s last production. ${ }^{25}$ His manuscript survives in a composite volume, bound with an Elizabethan copy of Lydgate's Life of our Lady, and its paper leaves are preceded by a parchment bifolium carrying Shirley’s ownership inscription and a table of contents. Originally, these smaller parchment leaves were probably not part of the same book, as only the first and last items in their list of contents matches the actual contents. ${ }^{26}$ Nonetheless, they open the book in grand style as, despite much fading and accumulation of dirt, f. $1 \mathrm{v}$ bears the ownership inscription common to all Shirley's surviving books (figure 3). ${ }^{27}$ It reads, 'ma • ioye $\bullet \mathrm{M} \bullet$ Shirley' in large and carefully executed textualis letters, with elaborated ascenders and descenders, a crown over the $\mathbf{M}$, and snowflakes at either side. Below are eight lines of Latin verse. The page announces not only Shirley’s ownership, but equally his sophistication, status, and scribal skill. 
The page is also inscribed with three merchant's marks. Two of these sit in the gap between the large inscription and the Latin lines, left-of-centre, while the third floats above the word 'ioye'. The three marks are similar but not identical; incorporating a reverse '4' shape with a cross to the left and an initial formed from the descender, the upper mark is smudged while the lower two are more carefully executed with decorative dotting on the stem and upper part. The bottom of each is decorated with a flourish similar to that added by Shirley to the descender on the $\mathbf{y}$ in 'ioye'. The mark almost certainly did not belong to Shirley, as it makes no appearance in any of his other title pages. If the initial incorporated into the marks is a b, it might have belonged to William Browne, the seventeenth-century collector who wrote his name at the top of f. 1r, and from whom Elias Ashmole acquired a number of manuscripts later bequeathed to the Bodleian Library. This is speculative, and various other names of later owners appear throughout the book, any of whom might be associated with the mark. More important as evidence that the mark did not belong to Shirley is the position of its variant forms on the page. The marks respond to Shirley's visual scheme by defying it, interrupting the symmetry and alignment of his inscriptions while mimicking his decorations, suggesting the recording of acquisition and the establishment of ownership.

Such disruptive intervention characterises a number of other anonymous marks in manuscript books. A copy of Piers Plowman contains four, drawn in red in the bottom margins of ff. $19 \mathrm{r}$ and $21 \mathrm{r}$ and twice in the back flyleaves. ${ }^{28}$ This signage implies ownership, as these marks would have been difficult to conceal or remove. Two fifteenth-century medical manuscripts contain marks alongside indications of user engagement, again suggesting ownership. In the first, a trilingual book of recipes, a mark was written on the front flyleaf. ${ }^{29}$ Also added to this page is an English recipe written in a different and less formal hand than the rest of the book. Its proximity to the mark and the similarity in the colour of the ink used for both suggest that the two additions were written by the same 
person, who apparently wanted both to customise their purchase and inscribe it. The second medical text, an English translation of John Arderne’s Fistula in Ano, was annotated by a variety of later owners. ${ }^{30}$ Many of these notes highlight passages dealing with specific complaints: one owner wrote 'emeroides' on each page where the condition is discussed (ff. $21 v, 26 v)$. The various owners of this book clearly found it useful, and alongside these indications of engagement is a merchant's mark on $\mathrm{f}$. 24r, added in the central space of the bottom margin created by the ruling for the two columns of text. This position, employing pre-existing features of layout, echoes the placement of marks in John Shirley’s book.

The disruptive incorporation of merchant's marks in these manuscripts suggests their ownership by individuals, but marks may also provide evidence for situations of multiple or shared ownership. A copy of The Prick of Conscience now in Oxford contains three different marks with no accompanying names or other information. ${ }^{31}$ In the left margin of $\mathrm{f} .115 \mathrm{v}$, the end of the poem, is a mark drawn in grey ink, possibly the same as was used for other scribbles on the same leaf. On the left of $\mathrm{f} .116 \mathrm{r}$ is a mark roughly similar in design, formed from a reverse '4' shape with a split descender, the right branch of which is crossed twice. Towards the bottom of the same page is a mark drawn in brown ink, with a similar split descender but a different top and an ' $\mathrm{X}$ ' shaped cross through the stem. This page has attracted many scribblings, including letter trials, drawings, and phrases in Latin. The presence of these three marks might indicate that this book was gifted several times or lent among a group of readers. Such a situation has not often been assessed in studies of medieval book ownership, but there are documented cases of book lending in fifteenth-century York and Ghent, so the exchange of this book within a circle of merchants or other professionally connected readers might account for its multiple marks. ${ }^{32}$

As a symbol of ownership, the merchant's mark was also a symbol of identity. Early scholarship suggested that marks functioned as signatures in trade networks, a convenient 
shorthand in a partially literate society. ${ }^{33}$ Marks have been described as the 'heraldry of the humble', wordless identifiers for those without noble birth. ${ }^{34}$ While 'humble' might be an inaccurate description for many of the book owners discussed here, the use of marks as a personal identifier explains their anonymous appearance in the examples discussed above: owners would have expected their marks to be recognised within their circle of connections, and among those to whom they might have lent their books. However, many sixteenthcentury owners of medieval manuscripts did not rely on the non-verbal alone, and combined marks with other inscriptions of ownership. Where a name, and sometimes more, is present, the merchant's mark signalled one facet of an owner's identity among many.

As a symbol of professional identity, marks often went hand in hand with expressions of piety. One such example is the business commonplace and account book of George Monoux, draper and alderman of the City of London. This book, known as his 'ledger', is a large paper manuscript begun by Monoux in 1507 recording purchases of land in the city alongside court records and rentals. ${ }^{35}$ Following the pastedown, it contains a flyleaf of liturgical music and a single bifolium on which Monoux wrote an ownership inscription (f. 2r). The page carries three four-line sections of text, at the top, middle, and bottom. In between the first two is a cross, and between the middle and bottom sections is an extremely elaborate merchant's mark. In the text, Monoux professes his piety:

In the Name off Almyghte god Father Sone and Holly gost / thre persondis and oon god Vnto Home I Humbly Beseche off mercy and grace and good convaiance in all my werkis

The conventionality of this address is emphasised by later alterations to the page which reflect shifts in the state position on devotional practice. The next lines, in which Monoux beseeches ‘our blyssid lady seint Mary and all the Holy company off hevyn' for their intercession have been crossed out, probably following the Protestant reforms of the later sixteenth century. ${ }^{36}$ Such expressions of faith were mediated by common practice and by the 
law. In the middle and bottom sections of text, Monoux describes his profession and the authenticity of the book ('And all the content off this boke ys wryttyn with the hande off me George Monoux'). Expressions of devotion and professionalism sit alongside one another on this page, echoed respectively by the cross and the mark.

Other combinations of professional and religious identity gestured beyond the individual owner to encompass a wider network. In a large and expensively produced copy of The Canterbury Tales, a man named Thomas Heed inscribed his mark at the end of the poem (figure 4). ${ }^{37}$ The book was probably produced in the third quarter of the fifteenth century, but the binding is thought to date from roughly $1500 .{ }^{38}$ Heed entered an obit into the liturgical calendar bound at the front of the book in 1510, so the manuscript as it survives today is likely to be in the same condition as when it was owned by Heed. ${ }^{39}$ The mark incorporates a circle containing Heed's initials, and is set within a phrase in two halves, 'O Mater dei' and 'Memento Mei'. Below the mark, Heed wrote an ownership note, 'pertinet Thomas heed ciuis Londoniens' ('belonging to Thomas Heed citizen of London'), and below this in larger letters the word 'Eleison', the Latinised form of Greek 'have mercy'. Heed’s profession is unclear, but there were ironmongers with the same name active in London in the early sixteenth century. ${ }^{40}$ Heed's use of a merchant's mark, and his identification with the city, suggests he may have been a relative.

His devout phrases take on a more intimate and personal character in the light of the obit. It reads, 'Obitus William Heed Anno x 1510 in die veneris hora quarta Ante Soll’ ('the death of William Heed in the year 1510 on Friday in the fourth hour before sunrise'). The will of a William Heed, who had two brothers named Thomas, survives in the National Archives. ${ }^{41}$ It is likely, then, that Thomas Heed inscribed the death of a sibling in his copy of the Tales. Taken together, Heed's inscriptions suggest he conceived of the book as a space 
for both devotion and memorialisation, a nexus of significations connecting Heed's piety and familial relationships in which the merchant's mark is embedded as a sign of his profession.

An even wider group is invoked in another copy of The Prick of Conscience now in the Huntington Library. In this book, the London grocer William Smart added an ownership inscription at the end of the poem complete with his merchant's mark and two short Marian prayers, one each in English and Latin. The mark bisects the words 'Iste liber' and 'partinet' (for 'pertinet') on the top line, and 'William' and 'Smart' on the bottom. To the right of the inscription is a signature: 'Smart groser'. The English prayer requests intercession specifically for the mercantile community:

god and houre lady that best may sawe al marchauntes by nyght and be day and be ther sped Amen quod William Smart ${ }^{42}$

Smart was a warden of the Grocer's Company in 1509, and his prayer might attest to a sense of corporate devotion. ${ }^{43}$ This book is much less lavish than the Heed Tales, smaller and on parchment of variable quality, but Smart's invocation of 'al merchauntes' nonetheless draws his Company together under divine protection.

Heed's and Smart's invocation of the communities surrounding them might have been intended to circulated within those communities. Heed's copy of the Tales was probably in some respects a public book. The manuscript states its value unambiguously; its border decorations, though smudged on the first leaf of the poem, are lavish and decorated in gold. The layout is generous, with wide margins and a complex ruling pattern creating space for running headers and annotation. Though it was likely inherited or acquired second hand, the book must still have been a statement of wealth, or at least of aspiration to wealth, in the reign of Henry VIII. In this context, Heed's mark at the end of the text is communicative, an act of self-fashioning for others to see. Smart's Prick of Conscience might have communicated something rather different: less spectacular but significantly more pious, this 
manuscript might for Smart have been an expression of humility despite, rather than in support of, his wealth.

Once they had acquired books, some mercantile owners passed them on to others. Where new owners added inscriptions, layers of acquisition sometimes came to be recorded around a single mark. This occurred in a copy of Gower's Confessio Amantis produced by the famous Scribe D, whose hand is present in the 'Trinity Gower' and several other books of Middle English verse. ${ }^{44}$ Like most of Scribe D’s books, the Confessio manuscript is a large and lavish London product, similar to Thomas Heed's Canterbury Tales in decoration and layout. On the verso of the front flyleaf is an enormous merchant's mark, spanning the full dimensions of the page. This mark appears again on the facing recto, where it inhabits the opening initial of the text, and near the end of the book, on f. $207 \mathrm{v}$, where it is drawn on a shield suspended from a tree.

The association in this last case with heraldic imagery is telling. During the sixteenth century, the manuscript came into the possession of two families, the Crispes and the Rawsons, several of whom entered notes of ownership into the book. The names of Thomas Crispe, Augustine Crispe, H. Rawson, Anne Rawson, and William Rawson all appear in the first few leaves, inscribed either within the large merchant's mark, in the border decoration on the facing leaf, or in the following folios. These two families were associated with the Company of Mercers: Thomas Crispe was warden in 1523, and the probable ancestor of the Rawsons who appear in the manuscript, Richard Rawson, was warden in $1483 .{ }^{45}$ Other Rawsons in the Company included Thomas and Christopher, who made wills in 1474 and 1519 respectively, and Avery and John, also active in the early sixteenth century. ${ }^{46}$ The Rawsons were originally from Yorkshire, and maintained connections with the county after Richard's move to London. ${ }^{47}$ Whichever family it was associated with, the merchant's mark 
on the heraldic shield indicates that their professional success might have lead to ambitions of ennoblement.

Thomas Crispe’s will was proved in 1532, the terminus ante quem for his ownership of the book, and William Rawson provides the only other securely dated period of ownership, in 1580 (f. 2r). ${ }^{48}$ It was probably during this forty-year gap that the book was owned by H. and Anne Rawson, whose names appear in the giant merchant's mark. The will of an Anne Rawson of Wakefield was made and proved in 1545, four years after the death of Thomas Crispe. ${ }^{49}$ Augustine Crispe is more difficult to trace: it is known from his will that Thomas had a son named Augustine, who perhaps acquired the book after his father's death before gifting it to the Rawsons, or $\mathrm{H}$. and Anne may have given it to him before he in turn gave it to William Rawson. Whatever the precise movements may have been, it is clear that the book passed between these two families of mercers, and each generation of ownership is inscribed in its pages. The merchant's mark is associated with the Crispe family, but all the names inhabiting it appear to have been written in the same hand. This suggests that the Rawsons, either H. and Anne, or the later William, compiled the various names found elsewhere in the book and inscribed each within the mark, perhaps in commemoration of the link between the two mercantile dynasties.

Another example of such modification appears in a manuscript discussed earlier. George Monoux's mark, as it appears in the ledger, bears the record of its transfer to another owner. Richard Vaughan, a servant of Monoux and one of the executors of his will, appears to have taken over the ledger at some point in its history. ${ }^{50}$ He wrote his initials in the front and back pastedowns along with his name (Latinised as 'Ricardus Vaughan'). He also incorporated his name into Monoux’s mark. The letters ‘aughan' were added to the right of the mark, joining the ' $\mathrm{V}$ '-shape which sits on the stem and from which a large flourish extends. Vaughan may also have added 'Et R' (for 'Ricardus') in the space enclosed by the 
' $\mathrm{V}$ ' shape, but these letters are less distinct. The ledger itself gives no information beyond this as to whether Vaughan took over Monoux’s business or property, but it seems a reasonable deduction that his various assertions of ownership indicate that the book was transferred to him, if not also the activity it records. This situation is not unprecedented: Wynkyn de Worde continued to use Caxton's mark when he assumed control of the printing business. ${ }^{51}$ The use of old marks by new owners suggests a role in legitimising this kind of continuation, and therefore the authority they could carry as symbols of mercantile identity.

Merchant's marks were also used to communicate identity within books that had a role in broader social transactions, beyond immediate professional or familial connections. The Chichester merchant William Bradbryge acquired a manuscript containing Latin liturgical material and Nicholas of Lyra's Postilla. ${ }^{52}$ The two texts were written by different scribes and were probably separate productions. The pages are ruled for two columns in both sections, but the ruling pattern is more elaborate and more carefully executed in the first, whose scribe also employed a more formal grade of script. The parchment is of very high quality, and the margins generous. Bradbryge inscribed his mark in the centre of the top margin on ff. 1r, 35r and 159r. The final instance is accompanied, in the bottom margin, by the words, 'Iste liber pertenethe ad William Bradbryge cicestrie mercatorem’. Bradbryge’s Latin appears to have been rather shaky, suggested by the English ending on 'pertenethe', which should read 'pertinet'. Why, then, did this merchant come to acquire an expensively produced book of preaching and academic material in Latin?

The answer has to do with Bradbryge’s connections to the church. Daniel Wakelin has suggested that these inscriptions, despite their errors, indicate the influence of 'clerical protocols' on lay formulations of book ownership. ${ }^{53}$ There may have been a direct context for this influence, as Bradbryge seems to have been involved in ecclesiastical politics. A presentation of 1546 records his institution as Rector of 'Westhorney', likely referring to the 
church of West Thorney a few miles from Chichester. ${ }^{54}$ A rectorship did not normally involve duties of lay spiritual and pastoral care, such as preaching, which were passed to a vicar. ${ }^{55}$ Bradbryge’s benefice, then, probably did not demand the duties of a parish priest, meaning that he would not have had to make use of the texts in his manuscript. His acquisition was perhaps an act of self-fashioning, projecting an image of his piety and concern for the wellbeing of the souls under his charge, while simultaneously communicating his professional identity.

A manuscript similar to Thomas Heed's Canterbury Tales and to the Crispe-Rawson Confessio also illuminates the function of merchant's marks in social and political transactions involving books. The manuscript is a copy of John Trevisa's English translation of De Proprietatibus Rerum, a weighty volume of 341 parchment folios. ${ }^{56}$ Like the Chaucer and Gower manuscripts, it contains full-page gold leaf border decoration and seven-line lombardic capitals at the start of each new book, and was produced in the first quarter of the fifteenth century. ${ }^{57}$

It was gifted by a sixteenth-century owner, William Radcliffe, to a man associated with the University of Cambridge, and may have played a role in Radcliffe's interest in education. Radcliffe was a merchant of Stamford in Lincolnshire, who served two terms as the town's mayor. ${ }^{58}$ He is known today as the founder of the Stamford School, one of only five chantry schools in England to have survived the Reformation, and created by his will in 1532. ${ }^{59}$ Radcliffe was associated with Lady Margaret Beaufort, the mother of Henry VII who founded Christ's and St John's Colleges in the University of Cambridge in the early sixteenth century. Beaufort had links to Stamford: she created an endowment supporting an anchoress there, and was part of the town's Guild of St Katherine. ${ }^{60}$ Her will mentions one 'William Ratclif [...] of Stamford'. ${ }^{61}$ This personal connection was reflected in the relationship 
between Beaufort and Radcliffe's foundations: the mayor of Stamford and St John's College were jointly responsible for the appointment of the Stamford School's headmaster. ${ }^{62}$

This background is relevant to the merchant's mark in Radcliffe's copy of Trevisa because the mark appears in the context of an ex dono notice. The book was gifted by Radcliffe to a 'John Cookes', identified as 'legum doctor', 'doctor of laws'. This term refers to the LL.D. degree, a doctorate of both civil and canon law, which was only awarded by the University of Cambridge, meaning Cookes must have been a student there. ${ }^{63}$ The 1988 edition of De Proprietatibus Rerum identifies Cookes in the archival record of Lincoln’s Inn, but on the basis of the doctorate indicated in Radcliffe's note this is unlikely to be the same person. ${ }^{64}$ The Inns of Court did not make provision for the study of civil or canon law, which was restricted to the universities. ${ }^{65}$ Instead, Cookes may be the man referred to in the Grace Book of the University of Cambridge, containing the Proctors' accounts and other records, in 1473 and $1474 .{ }^{66}$ Given Radcliffe's likely dealings with members of the University in the establishment of his school, it is probable that the gift of such an expensive manuscript had some function in cultivating or maintaining relationships within the institution.

Education was also a concern of George Monoux, who founded a grammar school in Walthamstow, and of Thomas Gresham, who established a college in the City endowed with seven professorships. Both institutions survive to this day, as Sir George Monoux College and Gresham College. Radcliffe's foundation, then, was one of a number established by merchants in the sixteenth century, and the inscriptions in his book construct an identity which legitimises this activity. The notice is written in grand style, using an elaborate and formal secretary script (f. 337v):

Bartholomeus De proprietatibus Rerum

Guillmus Radcliffe de Stamforde dono Gratuito dedit Ioanni Cookes Legum doctor 
The mark sits on the right side, and is one of the more intricate of the examples discussed here (figure 5). Its basic form is a '4' with an extra line forming a cross to the right and a split descender. The stem is highly elaborated, incorporating what are possibly an ' $\mathrm{S}$ ' and an ' $\mathrm{M}$ ', and a large ' $G$ ' which encircles the point at which the descender splits. The ' $G$ ' probably stands for the Latinised form of William, as Radcliffe calls himself in the notice, and so contributes to the sense of sophisticated and magisterial Latinity projected by it. This record of exchange styles the two men in the act of giving and receiving, incorporating expressions of Radcliffe's profession and Cookes' education. The notice must have struck later owners of the book; sections of it were recopied four times immediately below the original, partly in early modern hands, somewhat disrupting its effect.

The social and material contexts of Radcliffe's mark were crucial in determining its meanings, but the contexts in which marks appeared have often been ignored, or their evidence lost, in the centuries since. In recovering their role within the play of significations communicated by the material and written features of a book, merchant's marks become a rich form of bibliographical evidence. They illuminate the 'sociology of texts': as evidence that a manuscript belonged to a person embedded in trade or in other professional activities, marks can reveal the self-fashioning and exchange in which books participated. ${ }^{67}$ More than marginal annotations or added text, merchant's marks had a life outside the codex and prior to it; they were handed down through generations of mercantile families or to the inheritors of businesses, and copied on many other documents. They accrued a range of professional and dynastic significations deployed by their owners and bound up with the object on which they were written. 
The particular significance of merchant's marks is in their expression of a sometimes complex social status. Book owners like William Radcliffe sought to promote an image of learning and munificence, while a member of the Crispe or Rawson dynasties set their family symbol in a heraldic shield, implying a desire, actualised or not, for ennoblement. Mercantile wealth created opportunities for image-making, and the elaboration and refinement of some merchant's marks in the sixteenth-century demonstrates the new role they came to play in these projects as elegant symbols detached from the practical constraints of their former uses.

Merchant's marks also make a contribution to the study of book ownership. They demonstrate that medieval manuscripts were valued by their later owners for many reasons, including their usefulness in practical terms, their communication of status, sophistication and wealth, and their significance as gifts or public objects. They also attest to the afterlife of canonical works of Middle English literature in the sixteenth century. While the presence of marks in copies of Chaucer, Gower, and Trevisa is not necessarily representative of the broader pattern of their use, it does suggest that luxury metropolitan copies of these texts produced in the early fifteenth-century maintained their status and value for well over a century. Merchant's marks are at the interface between material object and social context, and they illuminate the role of the medieval manuscript book in early modern literary, professional and material culture.

\footnotetext{
My thanks are due to Daniel Wakelin, Seamus Dwyer, and Matthew Aiello for their comments on early drafts of this article, and to the journal's two anonymous reviewers for their insightful responses.

${ }^{1}$ Susan Foister, Holbein and England (New Haven: Yale University Press, 2004), pp. 206-14.

${ }^{2}$ Katrin Petter-Wahnschaffe, Hans Holbein und der Stalhof in London (Munich: Deutscher Kunstverlag, 2010), pp. 33-4.
} 


\footnotetext{
${ }^{3}$ Hans Holbein the Younger, The Merchant Georg Gisze, 1532, oil on oak, 85.7 x 97.5 cm, Berlin,
} Gemäldegalerie (@ Gemäldegalerie, Staatliche Museen zu Berlin, Berlin).

${ }^{4}$ Sir Thomas Gresham, 1544, oil on panel, London, The Mercers’ Company (@ The Mercers’ Company, London). For Gresham's early biography see pp. 17-18 of Ian Blanchard, 'Sir Thomas and the "House of Gresham”: activities of a mercer-merchant adventurer’, in Sir Thomas Gresham and Gresham College: Studies in the intellectual history of London in the sixteenth and seventeenth centuries, ed. by Francis Ames-Lewis (Aldershot: Ashgate, 1999), pp. 13-23.

${ }^{5}$ Ian Doolittle, The Mercer’s Company 1579-1959 (London: The Mercer’s Company, 1994), plate 1.

${ }^{6}$ F. A. Girling, English Merchant’s Marks: A Field Survey of Marks Made by Merchants and Tradesmen in England Between 1400 and 1700 (London: Oxford University Press, 1964), pp. 9-18.

${ }^{7}$ Girling, Marks, p. 9.

${ }^{8}$ Girling, Marks, pp. 58-9.

${ }^{9}$ Girling, Marks, pp. 37,

${ }^{10}$ Petter-Wahnschaffe, Holbein, pp. 29-33; Foister, Holbein, p. 208; Doolittle, Mercer's Company, plate 1.

${ }^{11}$ Anne Sutton, 'The Acquisition and Disposal of Books for Worship and Pleasure by Mercers of London in the Later Middle Ages', in Manuscripts and printed books in Europe, 1350-1550: packaging, presentation and consumption, ed. by Emma Cayley and Susan Powell (Liverpool: Liverpool University Press, 2013), pp. 95114; Kate Harris, 'Patrons, buyers and owners: the evidence for ownership, and the rôle of owners in book production and the book trade', in Book Production and Publishing in Britain 1375-1475, ed. by Jeremy Griffiths and Derek Pearsall (Cambridge: Cambridge University Press, 1989), pp. 163-199; Susan H. Cavanaugh, ‘A Study of Books Privately Owned in England 1300-1450' (unpublished doctoral thesis, University of Pennsylvania, 1980); and Chapter 2, 'English Bibles and their Owners', in Ian Green, Print and Protestantism in Early Modern England (Oxford: Oxford University Press, 2000), pp. 42-100.

${ }^{12}$ E. Gordon Duff, The English Provincial Printers, Stationers and Bookbinders to 1557 (Cambridge: Cambridge University Press, 1912), p. 58. Duff mentions the ‘trade-mark’ in the printer’s device of Ursyn Mylner.

${ }^{13}$ John MacLean, 'The Armory and Merchant’s Marks in the Ancient Church of Cirencester', Transactions of the Bristol and Gloucester Archaeological Society, 17 (1892-93), 268-322; William C. Ewing, 'Notices of the Norwich Merchant Marks’, Norfolk Archaeology, 3 (1852), 177-228; R. Fitch, 'Norwich Brewer’s Marks’, Norfolk Archaeology, 10 (1859), 313-330; J. Paul Rylands, ‘Merchants’ Marks and other Mediæval Personal 
Marks', Transactions of the Historic Society of Lancashire and Cheshire, 62 (1910), 1-34; W. B. Stevenson, 'Medieval Identification Marks and their Survivals in Scotland', Transactions of the Glasgow Archaeological Society, 13 (1954), 103-23.

${ }^{14}$ E. M. Elmhirst, Merchant's Marks, ed. by Leslie Dow (London: Harleian Society, 1959); Girling, Marks. ${ }^{15}$ Elmhirst, Marks, p. 39, itm. 560; p. 43, itm. 675. Elmhirst draws on examples in Duff, English Provincial Printers. Girling, Marks, pp. 110-11, 117-9.

${ }^{16}$ Matthew Champion, Medieval Graffiti: The Lost Voices of England's Churches (London: Ebury, 2015).

${ }^{17}$ Steven N. Zwicker, ‘The Reader Revealed', in The Reader Revealed, ed. by Sabrina Alcorn Baron (Washington, DC: Folger Shakespeare Library, 2001), pp. 11-17; William H. Sherman, Used Books: Marking Readers in Renaissance England (Philadelphia: University of Pennsylvania Press, 2008); Juliet Fleming, Graffiti and the Writing Arts of Early Modern England (London: Reaktion Books, 2010); Stephen Orgel, The Reader in the Book: A Study of Spaces and Traces (Oxford: Oxford University Press, 2015).

${ }^{18}$ Manuscripts and Printed Books, ed. by Cayley and Powell; Daniel Wakelin, ‘’Thys ys my boke”: Imagining the Owner in the Book', in Spaces for Reading in Later Medieval England, ed. by Mary Catherine Flannery and Carrie Griffin (New York: Palgrave Macmillan, 2016), pp. 13-33; and Jason Scott-Warren, 'Reading Graffiti in the Early Modern Book’, Huntington Library Quarterly, 73 (2010), 363-81.

${ }^{19}$ For Mylner and Jacobi, see Duff, English Provincial Printers, pp. 26, 55-8. For Copland, see Lotte Hellinga, William Caxton and Early Printing in England (London: British Library, 2010), pp. 100, 178-9.

${ }^{20}$ William Beattie, The Chepman and Myllar Prints (Edinburgh: Edinburgh Bibliographical Society, 1950); and The Chepman and Myllar Prints: Digitised Facsimiles with Introduction, Headnotes, and Transcription, ed. by Sally Mapstone (Edinburgh: The Scottish Text Society and The National Library of Scotland, 2008).

${ }^{21}$ Hellinga, Caxton, p. 100; and Elmhirst, Marks, p. 23, itm. 208.

${ }^{22}$ Philadelphia, Philadelphia Free Library, Widener MS 3.

${ }^{23}$ Eamon Duffy, Marking the Hours: English People and their Prayers 1240-1570 (New Haven: Yale University Press, 2006), p. 29, plate 17.

${ }^{24}$ Oxford, Bodleian Library, MS Ashmole 59. Shirley’s importance to English literary history is discussed in Margaret Connolly, John Shirley: Book Production and the Noble Household in Fifteenth-Century England (Aldershot: Ashgate, 1998), pp. 1-9.

${ }^{25}$ Italics represent expanded abbreviations.

${ }^{26}$ Connolly, John Shirley, pp. 145-50. 
${ }^{27}$ For illustrations of Shirley's other inscriptions, see Connolly, John Shirley, plates 3(i)-3(ix).

${ }^{28}$ Oxford, Bodleian Library, MS Bodley 815.

${ }^{29}$ London, British Library, Additional MS 4898.

${ }^{30}$ London, British Library, Additional MS 8093.

${ }^{31}$ Oxford, Bodleian Library, MS Laud misc. 601.

${ }^{32}$ Jo Ann Hoeppner Moran, ‘A “Common Profit” Library in Fifteenth-Century England and Other Books for Chaplains', Manuscripta, 28 (1984), 17-25; and Herman Brinkman, 'Het Comburgse handschrift en de Gentse boekproductie omstreeks 1400', Queeste, 5 (1998), 98-113.

${ }^{33}$ Elmhirst, Marks, p. vii. Similar points are made in Girling, Marks, pp. 9-10, Rylands, 'Merchants’ Marks', 23, and Charles Sisson, 'Marks as Signatures’, The Library, 9 (1928), 1-35.

${ }^{34}$ Sisson, 'Marks', 19.

${ }^{35}$ London, British Library, Additional MS 18783. Monoux dated the book on f. 2r.

${ }^{36}$ Compare examples in Duffy, Marking the Hours, pp. 168-70 (plates 110-12). See also the discussion of the conventions which structured financial accounts in Adam Smyth, Autobiography in Early Modern England (Cambridge: Cambridge University Press, 2010), pp. 61-72.

${ }^{37}$ Oxford, Bodleian Library, MS Arch. Selden B. 14, f. 309v

${ }^{38}$ M. C. Seymour, A Catalogue of Chaucer Manuscripts, 2 vols (Aldershot: Scolar, 1997), II, pp. 196-7, places the manuscript's scribe in '1450-75', and the binding 'c. 1500'.

${ }^{39}$ Confusion created by the presence of a wormhole above the ' 0 ' in the date of the obit leads Seymour, Catalogue, p. 197, to read '1518'. The date is in fact 1510.

${ }^{40}$ Henry Heed was an ironmonger who made his will in 1502. See London, National Archives, PROB 11/13/348, and Shannon McSheffrey, Marriage, Sex, and Civic Culture in Late Medieval London (Philadelphia, 2006), pp. 74-75.

${ }^{41}$ London, The National Archives, PROB/11/13/403.

${ }^{42}$ San Marino, Huntington Library, MS Hm 130, f. 120v.

${ }^{43}$ John Abernathy Kingdon and W. W. Grantham, List of the Wardens of the Grocer's Company from 1345 to 1907 (London: 1907), p. 15.

${ }^{44}$ Oxford, Corpus Christi College, MS 67. Scribe D was first discussed in A. I. Doyle and M. B. Parkes, 'The production of copies of the Canterbury Tales and the Confessio Amantis in the early fifteenth century', in Medieval Scribes, Manuscripts and Libraries: Essays presented to N. R. Ker, ed. by M. B. Parkes and Andrew 
G. Watson (London: Scolar, 1978), pp. 163-210; an identification has been suggested in Linne R. Mooney and Estelle Stubbs, Scribes and the City: London Guildhall Clerks and the Dissemination of Middle English Literature, 1375-1425 (Woodbridge: York Medieval Press, 2013), pp. 38-65.

${ }^{45}$ See the entry for MS 67 in R. M. Thomson, A Descriptive Catalogue of the Medieval Manuscripts of Corpus Christi College Oxford (Cambridge: Brewer, 2011), pp. 34-5.

${ }^{46}$ London, National Archives, PROB 11/6/210 (will of Thomas Rawson); PROB 11/19/188 (will of Christopher Rawson). Avery and John Rawson are discussed in Alison Hanham, The Celys and their World: An English Merchant Family of the Fifteenth Century (Cambridge, 1985), pp. 413-4; see also National Archives, SP 46/187/24, a document concerning Avery Rawson made in 1509.

${ }^{47}$ See Richard Rawson's will, and that of his widow Isabell, in James Raine and John William Clay, Testamenta Eboracensia: A Selection of Wills from the Registry at York, 6 vols (London: J.B. Nichols and Son, 1869), IV, pp. 130-1.

${ }^{48}$ Thomson, Descriptive Catalogue, p. 34, citing National Archives, PROB 11/24/178. Rawson’s inscription appears on f. 2r.

49 Thomson, Descriptive Catalogue, p. 34.

${ }^{50}$ S. T. Bindoff, The History of Parliament: The House of Commons 1509-1558, 3 vols (London: History of Parliament Trust, 1982), II, p. 613.

${ }^{51}$ Girling, Marks, p. 22, and Hellinga, Caxton, p. 131.

52 Oxford, Bodleian Library, MS e Musaeo 5.

${ }^{53}$ Wakelin, 'Imagining the Owner', p. 26.

${ }^{54}$ Chichester, West Sussex Records Office, Ep I/6/7.

55 See 'rector, n.', OED Online (Oxford University Press) <http://www.oed.com/view/Entry/160046> [accessed 3 July 2019].

${ }^{56}$ London, British Library, Additional MS 27944.

${ }^{57}$ The manuscript is dated in Linne Mooney, Simon Horobin, and Estelle Stubbs, 'London, British Library, MS Additional 27944', Late Medieval English Scribes, <http://www.medievalscribes.com/index.php?navtype=manuscripts\&navlocation=London\&browse=manuscript s\&navlibrary=British+Library\&id=155\&nav=off $>$ [accessed 3 July 2019]. See also Catalogue of Additions to the Manuscripts in the British Museum in the Years 1861-1875, 2 vols (London: British Museum, 1967), II, pp. $382-3$. 
58 John Drakard, The History of Stamford, in the County of Lincoln (Stamford, 1822), p. 315.

${ }^{59}$ B. L. Deed, A History of Stamford School (Stamford: Stamford School, 1954), p. 9.

${ }^{60}$ Michael K. Jones and Malcolm G. Underwood, The King’s Mother: Lady Margaret Beaufort, Countess of Richmond and Derby (Cambridge: Cambridge University Press, 1992), p. 132.

${ }^{61}$ A. C. Seward, T. G. Bonney, and R. F. Scott, Collegium Divi Johannis Evangelistae, 1511-1911 (Cambridge: Cambridge University Press, 1911), p. 116.

62 Deed, Stamford School, p. 9.

${ }^{63}$ A.B. Emden, A Biographical Register of the University of Oxford to A.D. 1500, 3 vols (Oxford: Clarendon, 1989), I, p. xlv; and Damian Riehl Leader, A History of the University of Cambridge: Volume I, The University to 1546 (Cambridge: Cambridge University Press, 1988), pp. 196-7.

${ }^{64}$ On the Properties of Things: John Trevisa's translation of Bartolomæus Anglicus De Proprietatibus Rerum, ed. by M. C. Seymour, 3 vols (Oxford: Clarendon, 1988), III, pp. 12-14.

${ }^{65}$ Sir John Baker, The Men of Court 1440 to 1550: A Prosopography of the Inns of Court and Chancery and the Courts of Law, 2 vols (London: Selden Society, 2012), p. 1; and T. A. R. Evans, 'The number, origins and careers of scholars', in The History of the University of Oxford: Volume II, Late Medieval Oxford, ed. by J. I. Catto and Ralph Evans (Oxford: Clarendon, 1992), pp. 485-38 (p. 521).

${ }^{66}$ A. B. Emden, A Biographical Register of the University of Cambridge to 1500 (Cambridge: Cambridge University Press, 1963), p. 148.

${ }^{67}$ D. F. McKenzie, Bibliography and the Sociology of Texts (Cambridge: Cambridge University Press, 1999). 